\title{
The Empowerment of Home Assimilation Reporting Supervision System Application (Sappar) for Correctional Assisted of Child Prisoners Residents
}

\author{
Ika Dewi Sartika Saimima ${ }^{1}$, Yuarini Wahyu Pertiwi², Widya Romasindah Aidy ${ }^{3}$, Elfrida Ade \\ Putri ${ }^{4}$, Herlawati Herlawati ${ }^{5}$, Rahmadya Trias Handayanto ${ }^{6}$ \\ $\left\{\right.$ herlawati@ubharajaya.ac.id ${ }^{5}$ \}
}

\begin{abstract}
Faculty of Law, Bhayangkara Jakarta Raya University, 17143, Indonesia ${ }^{1,3,4}$ Faculty of Psychology, Bhayangkara Jakarta Raya University, 17143, Indonesia ${ }^{2}$ Faculty of Computer Science, Bhayangkara Jakarta Raya University, 17143, Indonesia ${ }^{5}$ Faculty of Engineering, Universitas Islam 45 Bekasi, 17113, Indonesia ${ }^{6}$
\end{abstract}

\begin{abstract}
One of the issues in the COVID-19 pandemic is the liberation of prisoners in order to control the spread of the COVID-19 by rescuing the child prisoners through the program of assimilation and integration. This program is under the supervision of the advisor community using the SAPPAR application (System Application for Monitoring and Reporting of the House Assimilation) which has been disseminated by the local office (Kanwil) of ministry of law and human rights (Kemenkumham) in West Java, Indonesia. This study aims to determine the effectiveness of SAPPAR as an assimilation program of the correctional inmates (WBP). This application is used to facilitate the monitoring and supervision of children inmates while performing assimilation in their house. The study of sociological law (socio legal research) was conducted to describe the phenomena of assimilation program during the COVID-19 pandemic for the correctional child prisoners. A qualitative approach and descriptive data analysis were conducted. The study focuses on legal analysis and psychological behavior of the child prisoners during assimilation as well as community behavior analysis when receiving prisoners back to their environment, the interaction between children, and the community assistance.
\end{abstract}

Keywords: Assimilation, children of assisted residents, SAPPAR applications

\section{Introduction}

The COVID-19 pandemic has disrupted daily life of people in the world. The World Health Organization (WHO) reports that there have been 44,351,506 confirmed cases of COVID-19, including 1,171,255 deaths [1]. In Indonesia, data gathered on 29 October 2020 showed about 404,048 COVID-19 cases, with 329,778 people were recovered and 13,701 people died [2]-[4].

One issue in this current COVID-19 pandemic situation is the release of prisoners from prisons and detention centers due to overpopulation [5-6]. At the beginning of March 2020, the occupancy rate of correctional institutions and detainees in Indonesia reached 268,919 people, the over-crowded condition of Indonesia's LAPAS reached 102\% (ranging from 2-253\%) [7].

Overcrowded, congested and cramped are a main problem on most prisons [8]. In some prisons, overcrowding is so acute that prisoners were forced to sleep in shifts. Based on these 
conditions, the release of prisoners should be carried out because prisons have a high risk of COVID-19 infection [15].

The Indonesian government finally issued a regulation through the Ministry of Law and Human Rights Number M.HH-19.PK/01.04.04 concerning the release and the freeing of prisoners as well as child prisoners through assimilation and integration in regard to prevent and combat the spread of COVID-19. Child prisoners still have the right to legal protection [9-11]. Therefore, children having met the requirements can obtain the right of assimilation and integration [12].

This research was conducted at the penitentiary (LAPAS) in West Java province, Indonesia. Child prisoners, actually, should be placed in the correctional facility for children (LPKA), however, due to the full capacity of the LPKA, the child prisoners are incarcerated in original prisons and join with adult prisoners. There are show in Table 1.

Table 1. The number of child prisoners in West Java is presented in.

\begin{tabular}{llcccc}
\hline \multirow{2}{*}{ Local Office } & \multirow{2}{*}{ Period } & \multicolumn{2}{c}{ Detainee } & \multicolumn{2}{c}{ Prisoners } \\
\cline { 3 - 6 } & Januari & AL & AP & AL & AP \\
\hline \multirow{3}{*}{ West Java } & February & 54 & 1 & 107 & 1 \\
& March & 59 & 0 & 92 & 2 \\
& April & 29 & 0 & 77 & 2 \\
& May & 30 & 0 & 0 & 1 \\
& June & 31 & 0 & 75 & 1 \\
\hline TOTAL & & 240 & 1 & 40 & 1 \\
\hline
\end{tabular}

Table 1 shows that the number of child prisoners and child prisoners is still quite high. Therefore, the West Java LAPAS officers must think about the best efforts for correctional facility for child prisoner, in particular to avoid the spread of COVID-19.

To support the home assimilation program, the West Java Ministry of Law and Human Rights Regional Office launched the Home Assimilation Reporting Application System (SAPPAR). The launch of the SAPPAR application is a strategy for monitoring prisoners and child inmates undergoing a home assimilation program. The SAPPAR application is expected to help carry out the duties and roles of community guidance. In addition, this application is also expected to support the guiding and monitoring assimilated prisoners to avoid repeat criminal offenses (recidivism), obey the law and have an independent life when they return to society.

This paper raises the issue of whether the SAPPAR application can improve the compliance of child prisoners in reporting their condition when home assimilation.

\section{Method}

The method used in this study is socio-legal with a qualitative approach. According to Wheeler and Thomas in Banakar and Travers' book, social-legal studies is used as an interdisciplinary alternative and challenges to legal doctrinal studies [13]. 'Socio' in socio-legal studies does not refer to sociology or social science, but represents 'the interface with the context in which the law exists'. That is why, when socio-legal researchers use social theory for analytical purposes, they often tend not to address sociological or other social science issues, but legal issues and legal studies. 
Child-prisoners reporting is a form of compliance that is expected by the community supervisor. Legal studies on compliance are carried out through a qualitative and descriptive data analysis approach and focus on the legal analysis and psychological behavior of prisoners undergoing home assimilation through the SAPPAR application

\section{Results and Discussion}

The opportunity to assimilate is a basic principle that must be carried out to help prisoners re-socialize with the community. The thing that is most feared by a prisoner is the labeling given by the community. Negative sentiment as a prisoner will interfere the security and they tend to repeat the mistake as well as interfere the mental development of child prisoners. Child prisoners have to work hard to readjust into society and survive outside prisons. The child prisoners need mental and spiritual readiness to be accepted back by society. If they are not ready, as a result, child prisoners will commit violations and do not comply with the rules set during the assimilation process.

In the behaviorist theory, there is an incapacitation theory where punishment must be carried out so that the perpetrator does not repeat the crime and a rehabilitation theory where punishment is carried out to facilitate rehabilitation of the perpetrator. This means that this theory focuses on the behavior of the criminal offender. When the assimilation program is carried out, it means that the behavior of child prisoners has received approval from bureau of correctional facility (BAPAS) whether it is appropriate and complies with the rules.

\subsection{SAPPAR Workflow}

The assimilation and integration policies during the COVID-19 pandemic must of course be supported by adequate surveillance devices and trained human resources in handling child prisoners. Supervision of house assimilation through the SAPPAR application can currently be accessed by two types of users, namely Community Advisors (PK) and Community Assisted Citizens (WBP). Figure 1 show The SAPPAR application workflow is outlined in. 


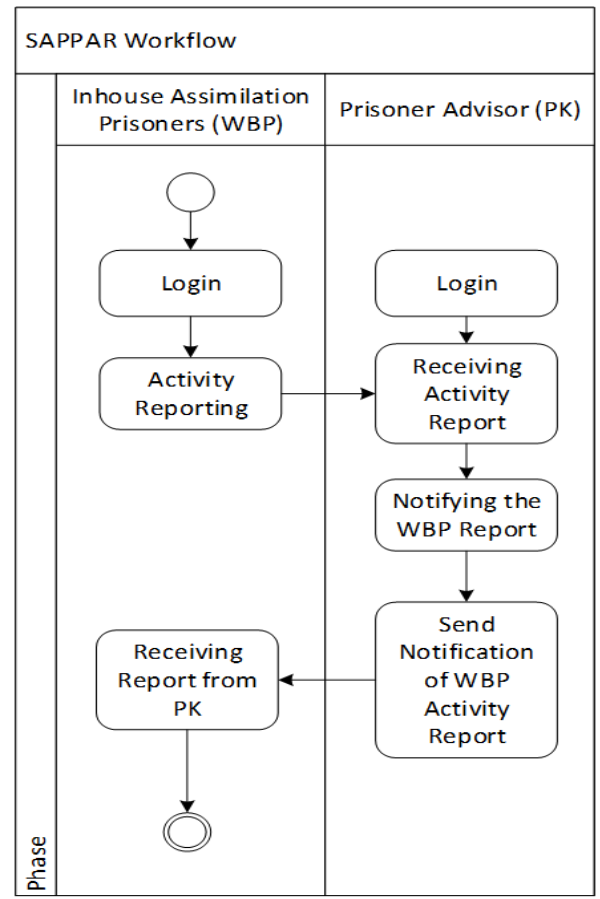

Fig.1. The SAPPAR application workflow is outlined in.

PK will set a schedule for WBP to report its activities. Within one week, WBP must make activity reports at least three times a week through the SAPPAR application. The report from WBP contains photos, descriptions, and the actual location of the WBP. Therefore, WBP will completely read the report. The SAPPAR application is also equipped with a reminder feature that can be set by the PK on the SAPPAR application backend. If the WBP does not report its activities, the WBP will be subject to sanctions.

\subsection{Survey Result}

Based on the survey, what a prisoner most afraid of is the negative sentiment given by the community. Negative sentiment of a prisoner invited a prisoner tends to repeat the crime. Also, this labeling will interfere with the mental development of child prisoners. Child prisoners have to work hard to readjust into society and survive outside prisons. It takes mental and spiritual readiness for a child prisoner to be accepted back by society. If they are not ready, as a result, child prisoners will commit violations and do not comply with the rules set during the assimilation process.

Monitoring of house assimilation through the SAPPAR application is currently accessible to 2 (two) types of users, namely Community Guidance (PK) and Community Assisted Citizens (WBP). Table 2 shows that there are three social controls for child assimilation program, namely: attachment, commitment, and involvement. Parents is the most attachment factor. 
Table 2. Social Control of the children of Prisoners.

\begin{tabular}{lccc}
\hline \multicolumn{1}{c}{ Attitude } & \multicolumn{3}{c}{ Attachment Factor } \\
\cline { 2 - 4 } & Parents & Survey Result \\
\cline { 2 - 4 } & $91 \%$ & $18 \%$ & Group Friends \\
\hline Relation to others & $(20$ people $)$ & $(4$ people $)$ & $9 \%$ \\
& $82 \%$ & $14 \%$ & $(2$ people $)$ \\
Understanding the rule & $(18$ people $)$ & $(3$ people $)$ & $18 \%$ \\
because of others & $9 \%$ & $45 \%$ & $(4$ people $)$ \\
$\begin{array}{l}\text { Doing the crime because of } \\
\text { the influence of others }\end{array}$ & $(2$ people $)$ & $(10$ people $)$ & $68 \%$ \\
\hline & Follow & Suggesting & $(15$ people $)$ \\
\hline Activity after crime & $27 \%$ & $55 \%$ & Avoiding \\
& $(6$ people $)$ & $(12$ people $)$ & $41 \%$ \\
& & & $(9$ people $)$ \\
\hline
\end{tabular}

Survey result shows that it can be explained that parents are the most influence factor of children behavior. This is because of the attachment of children to parents and more or less the cultivation of values from parents to children, but because this attachment is not positively developed so that in the end the children are more involved in activities with group friends or their games so that it eventually grows attachment. Referring to Hirschi's social control theory, it is clear that deviant behavior increases when the child's bond with the child weakens, resulting in a lack of peer supervision, good communication patterns and togetherness in warm and positive terms.

Table 3 shows that most child assimilation understand that an activity is a crime. Commitment is an element of social control that can influence children to do criminal acts. Based on survey results, it was found that more children knew enough and even knew about the rules. This is related to the criminal behavior they have committed; they understand that it is a violation of the law and can result in criminal sanctions. Unfortunately, even though they already understand the criminal act is still being committed, it is clear that their commitment to the rules and laws is classified as lacking.

Table 3. Commitment Factor

\begin{tabular}{lccc}
\hline & \multicolumn{3}{c}{ Commitment Factor } \\
\cline { 2 - 4 } Attitude & \multicolumn{3}{c}{ Survey Result } \\
\cline { 2 - 4 } & Fully Understand & $\begin{array}{c}\text { Half } \\
\text { Understand }\end{array}$ & $\begin{array}{c}\text { Do not } \\
\text { Understand }\end{array}$ \\
\hline Understand that an attitude is a crime & $41 \% \%$ & $41 \%$ & $18 \%$ \\
& $(9$ people $)$ & $(9$ people $)$ & $(4$ people $)$ \\
Understand that an attitude is related & $27 \%$ & $55 \%$ & $18 \%$ \\
to crime sentence & $(6$ people $)$ & $(12$ people) & $(4$ people $)$ \\
\hline
\end{tabular}

Table 4 shows the most child assimilation active in community as well as activity with parents and friends. Child prisoners are mostly active in participating in positive activities at school and also with family and friends. It means that each child as a criminal offender basically has a different level of activity and has the intention to join in good activities. However, most of them drop out of school and the lack of parents' control. Hirschi explained that positive activities or activities can minimize children from committing criminal acts because there are no more institutions that supervise or help instill good values. 
Table 4. Involvement Factor of Child Prisoners.

\begin{tabular}{lccc}
\hline \multirow{3}{*}{ Attitude } & \multicolumn{3}{c}{ Involvement Factor } \\
\cline { 2 - 4 } & Very Active & Active & $\begin{array}{c}\text { Do not } \\
\text { Active }\end{array}$ \\
\hline Involve in school and community activities & $50 \%$ & $32 \%$ & $18 \%$ \\
Involve in parent and friend activities & $(11$ people $)$ & $(7$ people $)$ & $(4$ people $)$ \\
& $41 \%$ & $41 \%$ & $18 \%$ \\
& $(9$ people $)$ & $(9$ people $)$ & $(4$ people $)$ \\
\hline
\end{tabular}

\subsection{SAPPAR Performance}

Based on the SAPPAR implementation analysis, several problems were found as follows. First, the application can only be accessed via smartphone with the Android's operating system. Even though smartphone users with the Android operating system are widely used today, there is still a possibility that WBP does not have a smartphone that complies with the SAPPAR application specifications. Second, the application can only be accessed by using the Internet network (on the network). The internet network has indeed spread in many regions in Indonesia. However, many areas still have internet signal problem but WBP smartphones must be connected to the internet. Therefore, they must have internet quota or have to go to a Wi-fi access location. This internet quota or Wi-fi access certainly requires a fee and this must be taken into account, whether the WBP has the funds to buy the internet quota or not. Third, this application usage practices are vulnerable for being manipulated. Reporting WBP activities through SAPPAR activities is vulnerable to being manipulated because WBP may make false reports that are not according to their circumstances. For example, a WBP reports a certain activity but in fact he is doing other activities and the photos uploaded in the SAPPAR application are only taken for reporting purposes only. In addition, the location of the WBP is not detected in real-time so that the WBP may go past the predetermined parameters.

The compliance is a form of obedience to the law with different qualities for each child prisoner. Obedience characteristic shows that child prisoners will be afraid of the sanctions that will be imposed if they don't report their condition. Obedience has the identification characteristic. It means that child prisoners will try to carry out the assimilation process as well as possible so that the report can be accepted by the social adviser. Obedience has also had internalization characteristic. It means that a child prisoner is obedient to report his condition because he understands that it is in accordance with the applicable legal rules. If these three characteristics are owned by child prisoners, then it can be ascertained that the SAPPAR application is very helpful in monitoring the assimilation process. On the other hand, if the noncompliance of child prisoners occurs due to difficulties in owning an Android smartphone and the cost to pay the quota, of course, the SAPPAR application cannot be used.

\section{Conclusion}

SAPPAR application as the child prisoner assimilation can be done optimally by taking into account the points as follows. The ability of child prisoners to provide smartphones with internet access. This situation happens usually because of economic problem (having no job). The compliance of child prisoners to report their condition during assimilation through the SAPPAR 
application is a key factor that help community counselors in the assimilation process. To avoid manipulation of the use of the SAPPAR application it is recommended to use a special device on the child's smartphone. This is to ensure that the presence of child prisoners isn't far from the established parameters.

\section{References}

[1] Organization WH. WHO Coronavirus Disease (COVID-19) Dashboard. https://covid19.who.int/. Published 2020. Accessed October 30, 2020.Charities Aid Foundation (CAF). 2018. World Giving Index 2018 A Global View of Giving Trend.

[2] Organization WH. WHO Coronavirus Disease (COVID-19) Dashboard. https://covid19.who.int/. Published 2020. Accessed October 30, 2020.

[3] KPCPEN. COVID-19 Spread History. https://covid19.go.id/peta-sebaran-covid19. Published 2020. Accessed October 30, 2020.

[4] Herlawati. COVID-19 Spread Pattern Using Support Vector Regression. PIKSEL Penelit Ilmu Komput Sist Embed Log. 2020;8(28):67-74.

[5] Handayanto RT, Herlawati H. Efektifitas Pembatasan Sosial Berskala Besar (PSBB) di Kota Bekasi Dalam Mengatasi COVID-19 dengan Model Susceptible-Infected-Recovered (SIR). J Kaji Ilm. 2020;20(2):119-124. doi:10.31599/jki.v20i2.119.

[6] Williams B, Ahalt C, Cloud D, Augustine D, Rorvig L, Sears D. Correctional Facilities In The Shadow Of COVID-19: Unique Challenges And Proposed Solutions. 2020.

[7] Lofgren E, Lum K, Horowitz A, Madubuonwu B, Fefferman N. The Epidemiological Implications of Incarceration Dynamics in Jails for Community, Corrections Officer, and Incarcerated Population Risks from COVID-19. 2020. doi:10.1101/2020.04.08.20058842.

[8] DITJENPAS. Prison Information. http://ditjenpas.go.id/category/warta-pas. Published 2020. Accessed October 30, 2020.

[9] Hewson T, Shepherd A, Hard J, Shaw J. Effects of the COVID-19 pandemic on the mental health of prisoners. The Lancet Psychiatry. 2020;7(7):568-570. doi:10.1016/S2215-0366(20)30241-8.

[10] Unesco V\& H. BASIC EDUCATION I United Nations Office at Vienna. Vienna: United Nation; 1995.

[11] Bartlett C, Dinsmore J, Gilbert JM, et al. Substance Abuse Treatment For Adults in the Criminal Justice System. Treatment Improvement Protocol (TIP) Series 44. Subst Abus Ment Heal Serv Adm. 2005. http://eric.ed.gov/?id=ED491574.

[12] Duwe G. The Use and Impact of Correctional Programming for Inmates on Pre- and Post-Release Outcomes. Natl Inst Justice. 2017;10097(2010):1-41.

[13] Yang H, Thompson JR. Fighting covid-19 outbreaks in prisons. BMJ. 2020;369(April):2020. doi:10.1136/bmj.m1362.

[14] Banakar, Reza and Travers M. Introduction: Law and Social Theory. 2ns ed. United Kingdom: Oxford University; 2013.

[15] Ramadhani, S. B., Dewi, D. A. S., \& Syafingi, H. M. (2020). Pengelolaan Dana Desa Untuk Peningkatan Kesejahteraan Masyarakat di Desa Kandangan Kabupaten Temanggung Tahun 20162018. Borobudur Law Review, 2(1), 40-52. 